\title{
COMPREHENSIVE NEWTON-RAPHSON MODEL FOR INCORPORATING UNIFIED POWER FLOW CONTROLLER IN LOAD FLOW STUDIES
}

\author{
M. Z. EL-Sadek, M. Abo-Zahhad, A. Ahmed, H.E. Zidan \\ Electrical Engineering Department, Faculty of Engineering, Assiut \\ University, Assiut, Egypt. $\quad$ E-mail: a_ahmed@aun.edu.eg
}

(Received Nov. 27, 2006, Accepted Jan. 20, 2007)

\begin{abstract}
Flexible AC Transmission Systems FACTS include unified power flow controllers (UPFC). Incorporation of a UPFC by a comprehensive Newton-Raphson power flow model into an existing MATLAB NewtonRaphson power flow algorithm is the subject of this paper. Unlike existing UPFC models available in open literature, this UPFC power flow model is modified to set control of active and reactive powers and voltage magnitude in any combination or to not control all of them. A set of analytical equations has been derived to provide better UPFC initial conditions. Their solution algorithm exhibits quadratic or near quadratic convergence characteristics. Based on this model, it is possible to estimate the UPFC control variables and the UPFC converters ratings. Also the effects of the UPFC coupling transformers impedances on the UPFC control variables and converters ratings are clarified and highlighted.
\end{abstract}

KEYWORDS: Flexible AC transmission systems (FACTS), Unified power flow controller (UPFC), Load flow analysis, MATLAB.

\section{INTRODUCTION}

Several publications have recently appeared in FACTS literature which describe the basic operating principles of the UPFC [1, 2]. However, most of the unified power flow controller UPFC models and have only addressed cases where the UPFC is connected between infinite busbars. Very little work has been done in developing suitable models for assessing the UPFCs behavior in large-scale power networks. This is particularly the case in the area of power flow analysis where, according to available literature, only two very constrained models have been published [3], [4]. Reference [3] takes a simpler approach. Here, the sending-end of the UPFC is transformed into a 
PQ bus, while the receiving-end is transformed into a PV bus and a standard NewtonRaphson load flow is carried out. This method is simple, but it will only work if the UPFC is used to control voltage magnitude, active power and reactive power, simultaneously. It is wished to control one or two variables; the method is no longer applicable. Moreover, since the UPFC parameters are computed after the load flow has converged, there is no way of knowing, during the iterative process, whether or not the UPFC parameters are within limits. Reference [4] takes the approach of modeling the UPFC as a series reactance. The voltage magnitude and angle of the series source are adjusted manually to achieve a power flow solution which, is hoped, will match the target power flow.

Trying to circumvent these limitations, a UPFC comprehensive NR power flow model has been proposed in [5]. This UPFC model is a straightforward extension of the power flow equations and, hence, it is suitable for incorporation into an existing NewtonRaphson NR load flow algorithm.

The main advantages which this UPFC power flow model has over the models reported in [3] and [4] are:

(a) In this model, the UPFC state variables are incorporated inside the Jacobian matrix and mismatch equations, leading to very robust iterative solutions. In this unified solution, the UPFC state variables are adjusted simultaneously with the nodal network state variables in order to achieve the specified control targets. Hence, the interaction between the network and the UPFC is better represented.

(b) This UPFC power flow model is completely general. It controls active and reactive power simultaneously as well as voltage magnitude. It can also be set to control one or more of those three variables above in any combination, or to control none of them.

(c) A set of analytical equations has been derived to provide good UPFC initial conditions. Providing no limit violations take place, the algorithm converges quadratically to a very tight power mismatch tolerance.

(d) The losses of the UPFC coupling transformers are taking into account.

\section{UPFC Construction}

Fig. (1) shows the basic circuit arrangement of the UPFC where it consists of two switching converters. These converters are operated from a common DC link provided by a DC storage capacitor. 


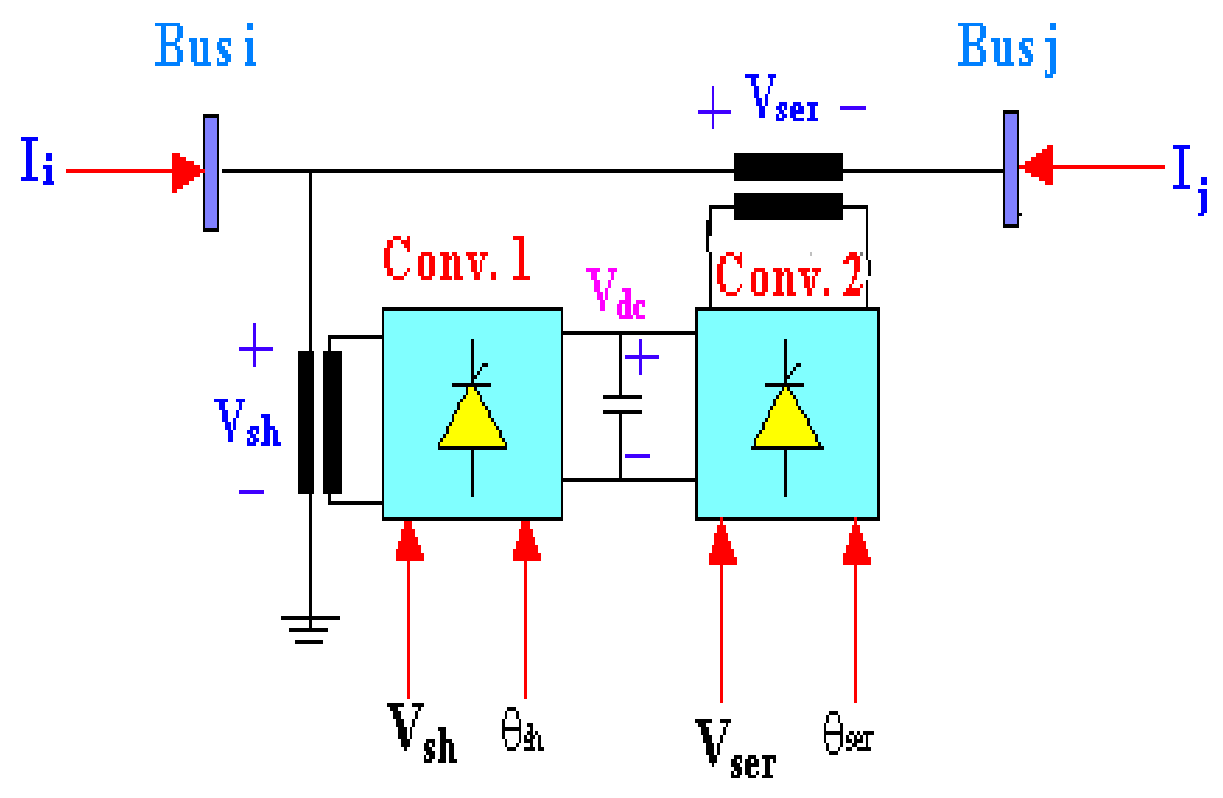

Figure 1: UPFC components.

\section{COMPREHENSIVE NEWTON-RAPHSON NR UPFC MODEL}

\subsection{UPFC Equivalent Circuit:}

The UPFC equivalent circuit shown in Fig. 2 is used to derive the steady-state comprehensive NR UPFC model. The equivalent circuit consists of two ideal voltage sources representing the fundamental Fourier series component of the switched voltage waveforms at the AC converter terminals. The source impedances included in the model represent the positive sequence leakage inductances and resistances of the coupling UPFC transformers.

The ideal voltage sources are:

$\mathrm{V}_{\mathrm{ser}}=\mathrm{V}_{\mathrm{ser}}\left(\cos \theta_{\mathrm{ser}}+\mathrm{j} \sin \theta_{\text {ser }}\right)$

$\mathrm{V}_{\mathrm{sh}}=\mathrm{V}_{\mathrm{sh}}\left(\cos \theta_{\mathrm{sh}}+\mathrm{j} \sin \theta_{\mathrm{sh}}\right)$

Where, $\mathrm{V}_{\text {ser }}$, and $\theta_{\text {ser }}$ are the controllable magnitude $\left(\mathrm{V}_{\text {ser min }} \leq \mathrm{V}_{\text {ser }} \leq \mathrm{V}_{\text {ser max }}\right)$ and angle $\left(0 \leq \theta_{\text {ser }} \leq 360^{\circ}\right)$ of the voltage source representing the series converter. The magnitude $\mathrm{V}_{\mathrm{sh}}$ and angle $\theta_{\mathrm{sh}}$ of the voltage source of the shunt converter are controlled between limits $\left(\mathrm{V}_{\text {sh min }} \leq \mathrm{V}_{\text {sh }} \leq \mathrm{V}_{\text {sh } \max }\right)$ and $\left(0 \leq \theta_{\text {sh }} \leq 360^{\circ}\right)$, respectively. 


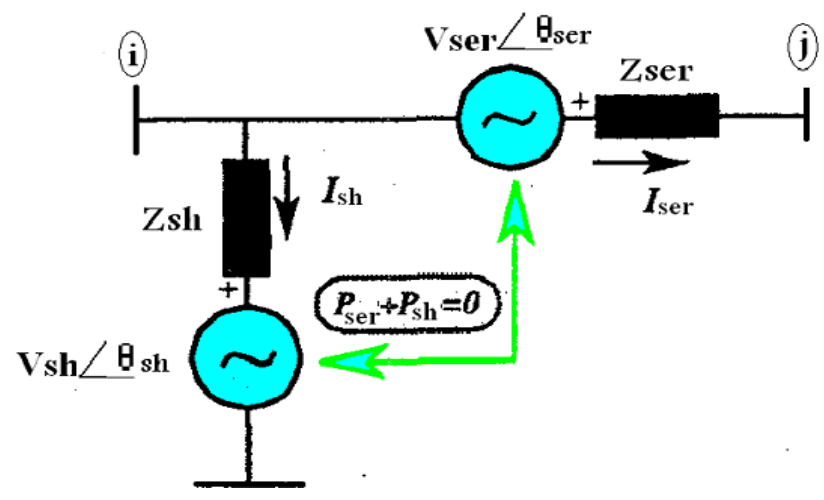

Figure 2: UPFC equivalent circuit.

\subsection{UPFC Power Equations}

Based on the equivalent circuit in Fig. 2, the active and reactive power equations are:

At node i:

$$
\begin{aligned}
\mathrm{P}_{\mathrm{i}} & =\mathrm{V}_{\mathrm{i}}^{2} \mathrm{G}_{\mathrm{ii}}+\mathrm{V}_{\mathrm{i}} \mathrm{V}_{\mathrm{j}}\left(\begin{array}{l}
\mathrm{G}_{\mathrm{ij}} \cos \left(\delta_{\mathrm{i}}-\delta_{\mathrm{j}}\right) \\
+\mathrm{B}_{\mathrm{ij}} \sin \left(\delta_{\mathrm{i}}-\delta_{\mathrm{j}}\right)
\end{array}\right)+\mathrm{V}_{\mathrm{i}} \mathrm{V}_{\mathrm{ser}}\left(\begin{array}{l}
\mathrm{G}_{\mathrm{ij}} \cos \left(\delta_{\mathrm{i}}-\theta_{\text {ser }}\right) \\
+\mathrm{B}_{\mathrm{ij}} \sin \left(\delta_{\mathrm{i}}-\theta_{\mathrm{ser}}\right)
\end{array}\right) \\
& +\mathrm{V}_{\mathrm{i}} \mathrm{V}_{\mathrm{sh}}\left(\begin{array}{l}
\mathrm{G}_{\mathrm{sh}} \cos \left(\delta_{\mathrm{i}}-\theta_{\mathrm{sh}}\right) \\
+\mathrm{B}_{\mathrm{sh}} \sin \left(\delta_{\mathrm{i}}-\theta_{\mathrm{sh}}\right)
\end{array}\right) \\
\mathrm{Q}_{\mathrm{i}} & =-\mathrm{V}_{\mathrm{i}}^{2} \mathrm{~B}_{\mathrm{ii}}+\mathrm{V}_{\mathrm{i}} \mathrm{V}_{\mathrm{j}}\left(\begin{array}{l}
\mathrm{G}_{\mathrm{ij}} \sin \left(\delta_{\mathrm{i}}-\delta_{\mathrm{j}}\right) \\
-\mathrm{B}_{\mathrm{ij}} \cos \left(\delta_{\mathrm{i}}-\delta_{\mathrm{j}}\right)
\end{array}\right)+\mathrm{V}_{\mathrm{i}} \mathrm{V}_{\mathrm{ser}}\left(\begin{array}{l}
\mathrm{G}_{\mathrm{ij}} \sin \left(\delta_{\mathrm{i}}-\theta_{\mathrm{ser}}\right) \\
-\mathrm{B}_{\mathrm{ij}} \cos \left(\delta_{\mathrm{i}}-\theta_{\mathrm{ser}}\right)
\end{array}\right) \\
& +\mathrm{V}_{\mathrm{i}} \mathrm{V}_{\mathrm{sh}}\left(\begin{array}{l}
\mathrm{G}_{\mathrm{sh}} \sin \left(\delta_{\mathrm{i}}-\theta_{\mathrm{sh}}\right) \\
-\mathrm{B}_{\mathrm{sh}} \cos \left(\delta_{\mathrm{i}}-\theta_{\mathrm{sh}}\right)
\end{array}\right)
\end{aligned}
$$

At node j:

$$
\begin{gathered}
\mathrm{P}_{\mathrm{j}}=\mathrm{V}_{\mathrm{j}}^{2} \mathrm{G}_{\mathrm{jj}}+\mathrm{V}_{\mathrm{j}} \mathrm{V}_{\mathrm{i}}\left(\begin{array}{l}
\mathrm{G}_{\mathrm{ij}} \cos \left(\delta_{\mathrm{j}}-\delta_{\mathrm{i}}\right) \\
+\mathrm{B}_{\mathrm{ij}} \sin \left(\delta_{\mathrm{j}}-\delta_{\mathrm{i}}\right)
\end{array}\right)+\mathrm{V}_{\mathrm{j}} \mathrm{V}_{\mathrm{ser}}\left(\begin{array}{l}
\mathrm{G}_{\mathrm{ij}} \cos \left(\delta_{\mathrm{j}}-\theta_{\mathrm{ser}}\right) \\
+\mathrm{B}_{\mathrm{jj}} \sin \left(\delta_{\mathrm{j}}-\theta_{\mathrm{ser}}\right)
\end{array}\right) \\
\mathrm{Q}_{\mathrm{j}}=-\mathrm{V}_{\mathrm{j}}^{2} \mathrm{~B}_{\mathrm{jj}}+\mathrm{V}_{\mathrm{j}} \mathrm{V}_{\mathrm{i}}\left(\begin{array}{l}
\mathrm{G}_{\mathrm{ij}} \sin \left(\delta_{\mathrm{j}}-\delta_{\mathrm{i}}\right) \\
-\mathrm{B}_{\mathrm{ij}} \cos \left(\delta_{\mathrm{j}}-\delta_{\mathrm{i}}\right)
\end{array}\right)+\mathrm{V}_{\mathrm{j}} \mathrm{V}_{\mathrm{ser}}\left(\begin{array}{l}
\mathrm{G}_{\mathrm{jij}} \sin \left(\delta_{\mathrm{j}}-\theta_{\mathrm{ser}}\right) \\
-\mathrm{B}_{\mathrm{jj}} \cos \left(\delta_{\mathrm{j}}-\theta_{\mathrm{ser}}\right)
\end{array}\right)
\end{gathered}
$$

Series converter: 


$$
\begin{gathered}
\mathrm{P}_{\mathrm{ser}}=\mathrm{V}_{\mathrm{ser}}^{2} \mathrm{G}_{\mathrm{jj}}+\mathrm{V}_{\mathrm{ser}} \mathrm{V}_{\mathrm{i}}\left(\begin{array}{l}
\mathrm{G}_{\mathrm{ij}} \cos \left(\theta_{\mathrm{ser}}-\delta_{\mathrm{i}}\right) \\
+\mathrm{B}_{\mathrm{ij}} \sin \left(\theta_{\mathrm{ser}}-\delta_{\mathrm{i}}\right)
\end{array}\right)+\mathrm{V}_{\mathrm{ser}} \mathrm{V}_{\mathrm{j}}\left(\begin{array}{l}
\mathrm{G}_{\mathrm{jj}} \cos \left(\theta_{\mathrm{ser}}-\delta_{\mathrm{j}}\right) \\
+\mathrm{B}_{\mathrm{jj}} \sin \left(\theta_{\mathrm{ser}}-\delta_{\mathrm{j}}\right)
\end{array}\right) \\
\mathrm{Q}_{\mathrm{ser}}=-\mathrm{V}_{\text {ser }}^{2} \mathrm{~B}_{\mathrm{jj}}+\mathrm{V}_{\mathrm{ser}} \mathrm{V}_{\mathrm{i}}\left(\begin{array}{c}
\mathrm{G}_{\mathrm{ij}} \sin \left(\theta_{\mathrm{ser}}-\delta_{\mathrm{i}}\right) \\
-\mathrm{B}_{\mathrm{ij}} \cos \left(\theta_{\mathrm{ser}}-\delta_{\mathrm{i}}\right)
\end{array}\right)+\mathrm{V}_{\mathrm{ser}} \mathrm{V}_{\mathrm{j}}\left(\begin{array}{l}
\mathrm{G}_{\mathrm{jj}} \sin \left(\theta_{\mathrm{ser}}-\delta_{\mathrm{j}}\right) \\
-\mathrm{B}_{\mathrm{jj}} \cos \left(\theta_{\mathrm{ser}}-\delta_{\mathrm{j}}\right)
\end{array}\right)
\end{gathered}
$$

Shunt converter:

$$
\begin{aligned}
& \mathrm{P}_{\mathrm{sh}}=-\mathrm{V}_{\mathrm{sh}}{ }^{2} \mathrm{G}_{\mathrm{sh}}+\mathrm{V}_{\mathrm{sh}} \mathrm{V}_{\mathrm{i}}\left(\begin{array}{l}
\mathrm{G}_{\mathrm{sh}} \cos \left(\theta_{\mathrm{sh}}-\delta_{\mathrm{i}}\right) \\
+\mathrm{B}_{\mathrm{sh}} \sin \left(\theta_{\mathrm{sh}}-\delta_{\mathrm{i}}\right)
\end{array}\right) \\
& \mathrm{Q}_{\mathrm{sh}}=\mathrm{V}_{\mathrm{sh}}{ }^{2} \mathrm{~B}_{\mathrm{sh}}+\mathrm{V}_{\mathrm{sh}} \mathrm{V}_{\mathrm{i}}\left(\begin{array}{l}
\mathrm{G}_{\mathrm{sh}} \sin \left(\theta_{\mathrm{sh}}-\delta_{\mathrm{i}}\right) \\
-\mathrm{B}_{\mathrm{sh}} \cos \left(\theta_{\mathrm{sh}}-\delta_{\mathrm{i}}\right)
\end{array}\right)
\end{aligned}
$$

The system admittance matrix elements are defined by:

$$
\begin{aligned}
& Y_{i i}=G_{i i}+j B_{i i}=Z_{s e r}{ }^{-1}+Z_{s h}{ }^{-1} \\
& Y_{j j}=G_{j j}+j B_{j j}=Z_{s e r}{ }^{-1} \\
& Y_{i j}=Y_{j i}=G_{i j}+j B_{i j}=-Z_{s e r}{ }^{-1} \\
& Y_{\text {ser }}=G_{s e r}+j B_{\text {ser }}=-Z_{s h}{ }^{-1}
\end{aligned}
$$

Assuming a loss free converter operation, the UPFC neither absorbs nor injects active power with respect to the AC system. Hence, the active power supplied to the shunt converter, $\mathrm{P}_{\mathrm{sh}}$, must overcome the active power demanded by the series converter, $\mathrm{P}_{\mathrm{ser}}$, i.e.

$\mathrm{P}_{\mathrm{ser}}+\mathrm{P}_{\mathrm{sh}}=0$

\subsection{UPFC Jacobian Equations}

The UPFC linearized power equations are combined with the linearized system of equations corresponding to the rest of the network,

$f(x)=[J][\Delta x]$

Where,

$$
[\mathrm{f}(\mathrm{x})]=\left[\Delta \mathrm{P}_{\mathrm{i}} \Delta \mathrm{P}_{\mathrm{j}} \Delta \mathrm{Q}_{\mathrm{i}} \Delta \mathrm{Q}_{\mathrm{j}} \Delta \mathrm{P}_{\mathrm{ij}} \Delta \mathrm{Q}_{\mathrm{ij}} \Delta \mathrm{P}_{\mathrm{bb}}\right]^{\mathrm{T}}
$$

$\Delta \mathrm{P}_{\mathrm{bb}}$ is the power mismatch given by Equation 15 and the superscript $T$ indicates transposition. $[\Delta \mathrm{x}]$ is the solution vector and $[\mathrm{J}]$ is the Jacobian matrix. For the case 
when the UPFC controls voltage magnitude at the AC shunt converter terminal (node $i$ ), active power flowing from node $j$ to node $i$ and reactive power injected at node $j$, and assuming that node $j$ is PQ-type, the solution vector is:

$$
[\Delta \mathrm{X}]=\left[\Delta \delta_{\mathrm{i}} \Delta \delta_{\mathrm{j}} \frac{\Delta \mathrm{V}_{\text {sh }}}{\mathrm{V}_{\mathrm{sh}}} \frac{\Delta \mathrm{V}_{\mathrm{j}}}{\mathrm{V}_{\mathrm{j}}} \Delta \theta_{\text {ser }} \frac{\Delta \mathrm{V}_{\text {ser }}}{\mathrm{V}_{\text {ser }}} \Delta \theta_{\text {sh }}\right]^{\mathrm{T}}
$$

and the Jacobian matrix $\mathbf{J}$ can be expressed as Eqn. 16. If the UPFC voltage control is deactivated, the third column of Eqn. 19 is replaced by partial derivatives of the UPFC mismatch powers with respect to the nodal voltage magnitude $\mathrm{V}_{\text {i. }}$. Moreover the shunt voltage magnitude increment in Eqn. 18 is replaced by the nodal voltage magnitude increment at node $\mathrm{i}\left(\Delta \mathrm{V}_{\mathrm{i}} / \mathrm{V}_{\mathrm{i}}\right)$. In this case, $\mathrm{V}_{\mathrm{sh}}$ is maintained at a fixed value within the prescribed limits.

\section{UPFC INITIAL CONDITIONS AND LIMITS VERIFICATION}

Good starting conditions are mandatory in any iterative process. The solution of the load flow equations does not differ in this respect. Engineering judgment indicates that for the simple case in which no controlled buses or branches are present, 1 p.u. voltage magnitude for all PQ buses and 0 voltage angle for all buses provide a suitable starting condition. However, if controllable devices are included in the analysis, the issue is not clear cut as the case above. For the UPFC, a set of equations which give good initial estimates can be obtained from the nodal and constraint UPFC power flow equations by assuming lossless converter valves and coupling transformers operation and null nodal voltage angles.

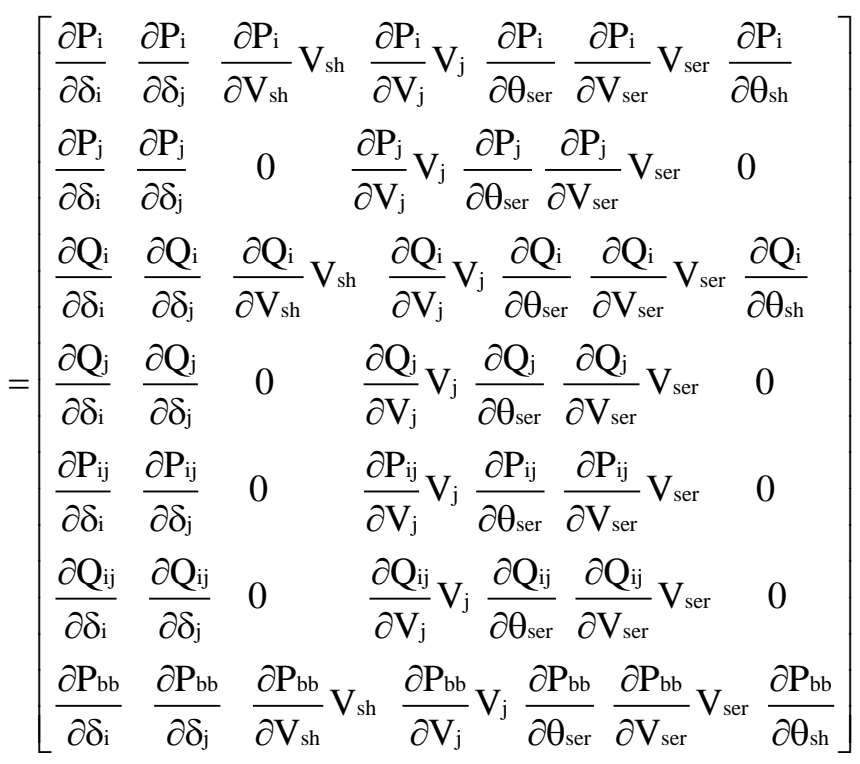




\subsection{Series Source Initial Conditions}

For specified nodal powers at node $\mathrm{j},\left(\mathrm{P}_{\text {jref }}\right.$ and $\left.\mathrm{Q}_{\mathrm{jref}}\right)$, the solution of Eqns. (5) and (6) yields,

$$
\begin{aligned}
& \theta_{\text {ser }}^{\circ}=\tan ^{-1}\left(\frac{P_{\text {jref }}}{C I}\right) \\
& \mathrm{V}_{\text {ser }}^{\circ}=\left(\frac{X_{\text {ser }}}{V^{\circ}{ }_{j}}\right) \sqrt{\mathrm{P}^{2}{ }_{\text {jref }}+\mathrm{CI}^{2}}
\end{aligned}
$$

Where

$$
\begin{aligned}
& C I=Q_{\text {jef }}-\frac{V^{\circ}{ }_{j}}{X_{\text {ser }}}\left(V^{\circ}{ }_{j}-V^{\circ}{ }_{i}\right) \text { if } V^{\circ}{ }_{j} \neq V^{\circ}{ }_{i} \\
& C I=Q_{\text {jref }} \text { if } V^{\circ}{ }_{j}=V^{\circ}{ }_{i}
\end{aligned}
$$

With: $X_{\text {ser }}$ is inductive reactance of the series source and the superscript ${ }_{0}$ indicates initial value.

\subsection{Shunt Source Initial Conditions}

An equation for initializing the shunt source angle can be obtained by substituting Equations (7) and (8) into Equation (15) and performing some manipulations to get:

$$
\theta_{\text {sh }}^{\circ}=-\sin ^{-1}\left(\frac{\left(\mathrm{V}^{\circ}{ }_{i}-V^{\circ}{ }_{j}\right) \mathrm{V}^{\circ}{ }_{\text {ser }} X_{\text {sh }} \sin \left(\theta_{\text {ser }}\right)}{V^{\circ}{ }_{\text {sh }} V^{\circ}{ }_{i} X_{\text {ser }}}\right)
$$

where $\mathrm{X}_{\mathrm{sh}}$ is the inductive reactance of the shunt source.

When the shunt converter is acting as a voltage regulator, the voltage magnitude of the shunt source is initialized at the target value and then it is updated at each iteration. Otherwise, if the shunt converter is not acting as a voltage regulator, the voltage magnitude of the shunt source is kept at a fixed value within prescribed limits, $\left(\mathrm{V}_{\text {sh min }} \leq \mathrm{V}_{\mathrm{sh}} \leq \mathrm{V}_{\text {sh max }}\right)$ for the whole iterative process.

\subsection{Limits Verification of The UPFC Controllable Variables}

The main advantages that this UPFC model has over the UPFC decoupled power flow model [3] and UPFC injection power flow model [4] is that the UPFC control variables are adjusted simultaneously with the nodal network state variables in order to achieve the specified control target. Hence, the interaction between the network and the UPFC is better represented and the limits of the UPFC state variables can be identified inside the power flow program. If a limit violation occurs in one of the voltage magnitudes, it is fixed at the offending limit and the regulated variable is freed. In this situation no further attempts are made to control this regulated variable for the remaining of the iterative process. Conversely, the voltage phase angles of both voltage sources are never fixed, since they are naturally circumscribed between the limits $0-2 \pi$. If the violation occurs in the series voltage source, the active and reactive 
power flow across this source will vary in an unrestricted manner. Similarly, if the violation occurs in the shunt voltage source, the reactive power injection contributed by this source will also vary in an unrestricted manner. These voltage phase angle changes ensure that Eqn. (15) is always satisfied.

\section{STUDIED SYSTEM}

The six-bus Ward Hall network shown in Fig. 3 has been used as a test system to verify the use of the UPFC comprehensive NR power flow model. UPFC is connected between buses 1 and 4, near bus 4 . Bus 7 is defined as auxiliary bus to connect UPFC.

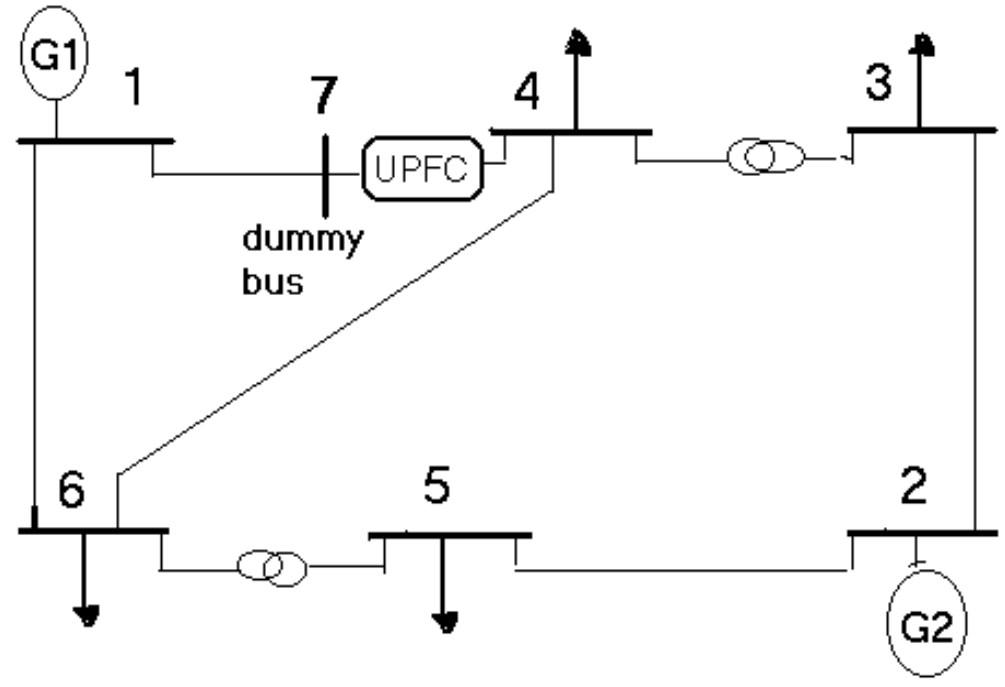

Figure 3: Six-bus Ward Hall network

\subsection{Base Case Without UPFC}

Table (1) shows the voltage magnitude and angle at bus 4 and the active and reactive power from bus 4 to bus 1 before connecting the UPFC.

Table 1: The voltage magnitude and angle at bus 4 and the active and reactive power in line 4-1 before UPFC connection.

\begin{tabular}{|c|c|c|c|}
\hline $\begin{array}{c}\mathrm{V}_{4} \\
(\mathrm{pu})\end{array}$ & $\begin{array}{c}\theta_{4} \\
(\mathrm{deg})\end{array}$ & $\begin{array}{c}\mathrm{P}_{4-1} \\
(\mathrm{MW})\end{array}$ & $\begin{array}{c}\mathrm{Q}_{4-1} \\
(\mathrm{MVAR})\end{array}$ \\
\hline 0.9526 & -9.922 & -48.846 & -10.480 \\
\hline
\end{tabular}

\subsection{UPFC Application}

In this section it is required to find the UPFC control variables i.e., ( $\mathrm{V}_{\text {ser }} \angle \theta_{\text {ser }}$ and $\left.\mathrm{V}_{\mathrm{sh}} \angle \theta_{\text {sh }}\right)$ and also the UPFC converters ratings i.e. . ( $\mathrm{P}_{\mathrm{ser}}, \mathrm{Q}_{\mathrm{ser}}, \mathrm{P}_{\mathrm{sh}}$, and $\left.\mathrm{Q}_{\mathrm{sh}}\right)$ that required to adjust the voltage magnitude at bus 4 and the active and reactive power in 
line 4-1 according to the control parameters values specified in table (2). Assuming the control parameters $\mathrm{V}_{\text {ref, }}, \mathrm{P}_{\text {ref }}$ and $\mathrm{Q}_{\text {ref }}$ are the values given in table (2).

Table 2: Control parameters of the system

\begin{tabular}{|c|c|c|}
\hline $\mathrm{V}_{\text {ref }}(\mathrm{pu})$ & $\mathrm{P}_{\text {ref }}(\mathrm{MW})$ & $\mathrm{Q}_{\mathrm{ref}}(\mathrm{Mvar})$ \\
\hline 1.00 & -50 & -5 \\
\hline
\end{tabular}

Those control parameters of the system are entered as inputs data in the power flow program. The UPFC control variables ( $\mathrm{V}_{\mathrm{ser}} \angle \theta_{\text {ser }}$ and $\left.\mathrm{V}_{\mathrm{sh}} \angle \theta_{\mathrm{sh}}\right)$ will be directly obtained as outputs from power flow program together with the normal power flow results.

Tables (3) and (4) show the UPFC control variables and the UPFC converters ratings that required to adjust the voltage magnitude at bus 4 and the active and reactive power in line 4-1 with the values shown in table (2) respectively, when $X_{\text {ser }}=X_{\text {sh }}=0.1$ p.u. and $\mathrm{R}_{\mathrm{ser}}=\mathrm{R}_{\mathrm{sh}}=0$.

Table 3: UPFC control variables.

\begin{tabular}{|c|c|c|c|}
\hline $\mathrm{V}_{\text {ser }}(\mathrm{pu})$ & $\theta_{\text {ser }}(\mathrm{deg})$ & $\mathrm{V}_{\mathrm{sh}}(\mathrm{pu})$ & $\theta_{\text {sh }}(\mathrm{deg})$ \\
\hline 0.0707 & 53.11 & 1.0129 & -9.598 \\
\hline
\end{tabular}

Table 4: UPFC converters ratings.

\begin{tabular}{|c|c|c|c|}
\hline $\begin{array}{c}\mathrm{P}_{\text {ser }} \\
(\mathrm{MW})\end{array}$ & $\begin{array}{c}\mathrm{P}_{\text {sh }} \\
(\mathrm{MW})\end{array}$ & $\begin{array}{c}\mathrm{Q}_{\text {ser }} \\
(\text { Mvar })\end{array}$ & $\mathrm{Q}_{\text {sh }}$ (Mvar) \\
\hline 1.0 & -9.524 & 0.973 & -10.2 \\
\hline
\end{tabular}

\subsection{Effects of UPFC Coupling Transformers Impedances on UPFC Control Variables and UPFC Converters Ratings:}

The effects of UPFC coupling transformers impedances on the UPFC control variables and consequently, the UPFC converters ratings will be cleared in this section. The UPFC is set to control the voltage magnitude and active and reactive power flows at the values as those specified in Table (2). The UPFC control variables and converters ratings corresponding to different combinations of source impedances are shown in Figs. 4 to 7. Figs. 4 and 5 show the variation of the UPFC control variables and converters ratings versus $X_{\text {ser }}$ at different values of $X_{\mathrm{sh}}(0.01,0.05$, and 0.1 p.u.) and the sources resistances are neglected i.e. $R_{\text {ser }}=R_{\text {sh }}=0$. Figs. 6 and 7 show the variation of the UPFC control variables and converters ratings versus $R_{\text {ser }}$ at different values of $R_{\mathrm{sh}}(0.0,0.02$, and 0.04 p.u. $)$ and the sources reactances are $X_{\text {ser }}=X_{\text {sh }}=0.1$ p.u.

From these figures, it is possible to conclude that: 
(a) The series voltage magnitude $V_{\text {ser }}$ is more sensitive to $X_{\text {ser }}$, low sensitive to $R_{\text {ser }}$, very low sensitive to $R_{\text {sh }}$, and not affected by $X_{\text {sh. }}$. It is possible to say that $V_{\text {ser }}$ is affected only by its own impedance $\mathrm{Z}_{\text {ser }}$.

(b) The series voltage angle $\theta_{\text {ser }}$ is affected only by the series source impedance $Z_{\text {ser }}$.

(c) The shunt source variables $V_{\text {sh }} \angle \theta_{\text {sh }}$ are affected by the shunt source impedance $Z_{\text {sh }}$ $=\mathrm{R}_{\mathrm{sh}}+\mathrm{j} \mathrm{X}_{\mathrm{sh}}$ and the series source resistance $\mathrm{R}_{\mathrm{ser}}$. It is not affected by $\mathrm{X}_{\mathrm{ser}}$ at all.

(d) The converters active power $\left(\mathrm{P}_{\text {ser }}\right.$, and $\left.\mathrm{P}_{\text {sh }}\right)$ are affected only by $\mathrm{R}_{\text {ser }}$.

(e) The series converter reactive power $Q_{\text {ser }}$ is affected by $Z_{\text {ser }}$ only.

(f) The shunt converter reactive power $Q_{\text {sh }}$ is affected by the series source resistance $R_{\text {ser }}$ and the shunt source reactance $X_{\text {sh }}$.
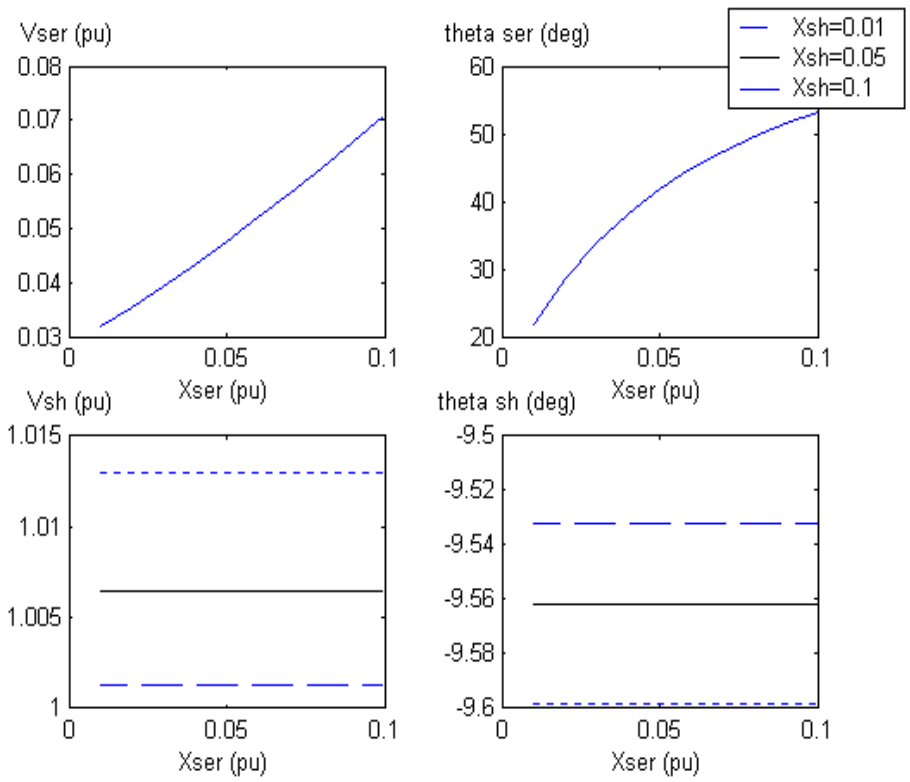

Figure 4: Variation of UPFC control variables versus $X_{\text {ser }}$.
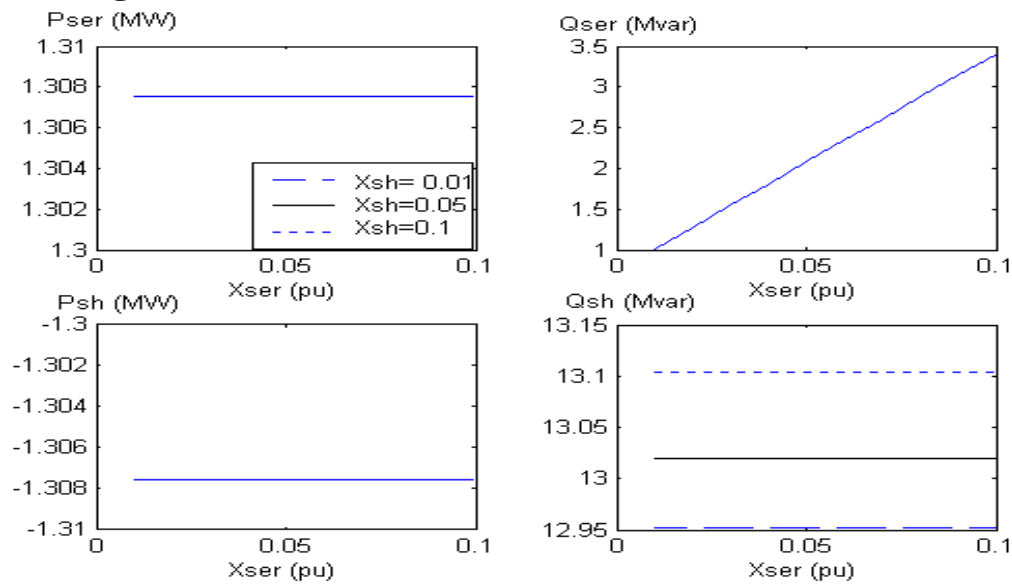

Figure 5: Variation of UPFC converters ratings versus $X_{\text {ser }}$. 

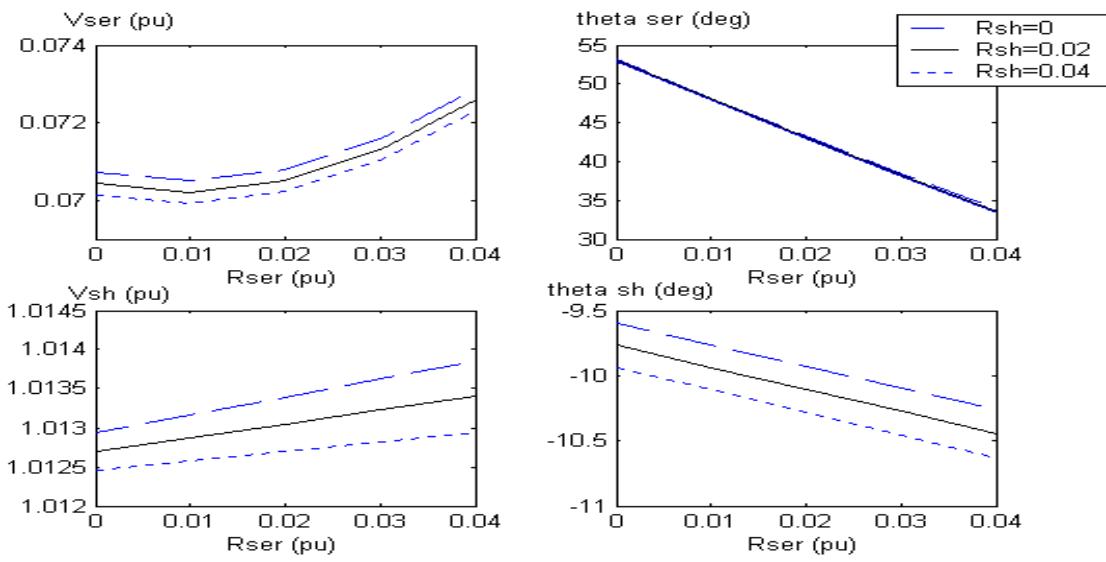

Figure 6: Variation of UPFC control variables versus $\mathrm{R}_{\text {ser }}$.
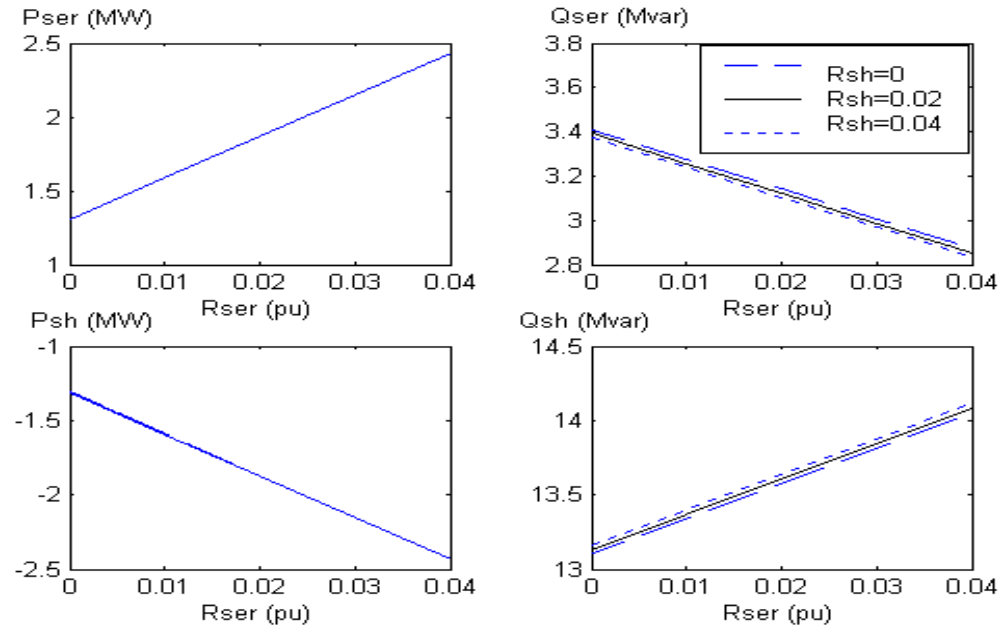

Figure 7: Variation of UPFC converters ratings versus $\mathrm{R}_{\text {ser }}$.

\subsection{Effects of UPFC Coupling Transformers Impedances When The Voltage Magnitude Control is Deactivated}

In this section, it is aimed to show the effect of the UPFC coupling transformers impedances on the UPFC control variables when the UPFC is set to control the active and reactive power flows at the same values as those specified in Table (2) and the voltage magnitude control at bus 4 is deactivated. The shunt source voltage magnitude is assumed to be fixed at 1.0 p.u. The UPFC control variables and converters ratings corresponding to different combinations of source impedances are shown in Figs. 8-11. Figs. 8 and 9 show the variation of the UPFC control variables and converters ratings versus $X_{\text {ser }}$ at different values of $X_{\text {sh }}(0.01,0.05$, and 0.1 p.u.) and the sources resistances are neglected i.e. $R_{\text {ser }}=R_{\text {sh }}=0$. Figures 9 and 10 show the variation of the UPFC control variables and converters ratings versus $R_{\text {ser }}$ at different values of $R_{\text {sh }}$ $(0.0,0.02$, and 0.04 p.u. $)$ and the sources reactances are $X_{\text {ser }}=X_{\text {sh }}=0.1$ p.u.

From these figures, it can conclude that: 
(a) The series voltage magnitude $V_{\text {ser }}$ is more sensitive to $X_{\text {ser }}$, low sensitive to $R_{\text {ser }}$, very low sensitive to $X_{\text {sh }}$, and not affected by $R_{\text {sh }}$. It is possible to say that $V_{\text {ser }}$ is affected only by its own impedance $\mathrm{Z}_{\text {ser }}$.

(b) The series voltage angle $\theta_{\text {ser }}$ is affected by the series source impedance $Z_{\text {ser }}$, it has small sensitivity to $\mathrm{X}_{\mathrm{sh}}$.

(c) The voltage magnitude at bus 4 and the shunt source angle $\theta_{\text {sh }}$ are more sensitive to $\mathrm{X}_{\text {sh }}$ and $\mathrm{R}_{\text {ser }}$, low sensitive to $\mathrm{R}_{\text {sh }}$.

(d) The converters active power $\left(\mathrm{P}_{\text {ser }}\right.$, and $\left.\mathrm{P}_{\mathrm{sh}}\right)$ are affected only by $\mathrm{R}_{\text {ser }}$ and $\mathrm{X}_{\text {sh }}$.

(e) The series converter reactive power $Q_{\text {ser }}$ is affected by $Z_{\text {ser }}$ only.

(f) The shunt converter reactive power $Q_{\text {sh }}$ is affected by the series source resistance $\mathrm{R}_{\text {ser }}$ and the shunt source reactance $\mathrm{X}_{\mathrm{sh}}$
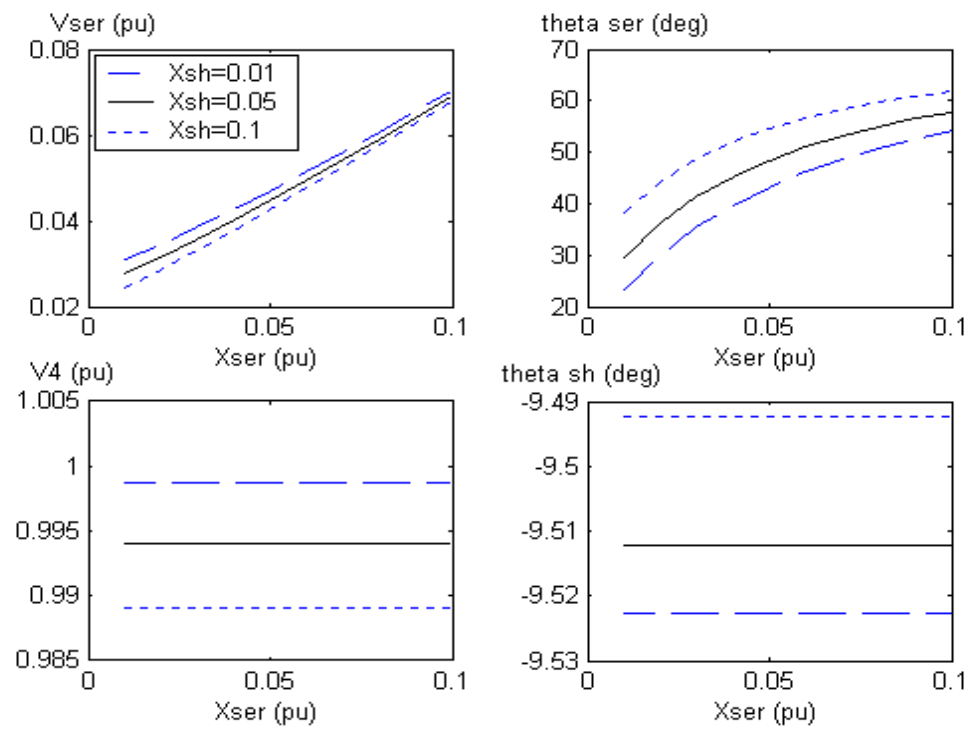

Figure 8: Variation of UPFC control variables versus $\mathrm{X}_{\text {ser. }}$.
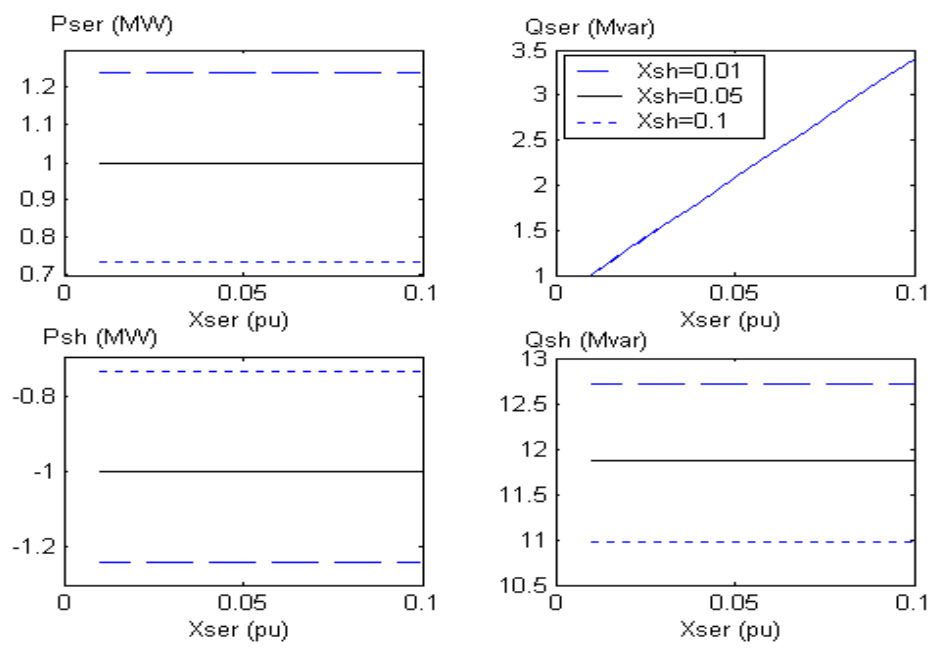

Figure 9: Variation of UPFC converters ratings versus $\mathrm{X}_{\text {ser }}$. 

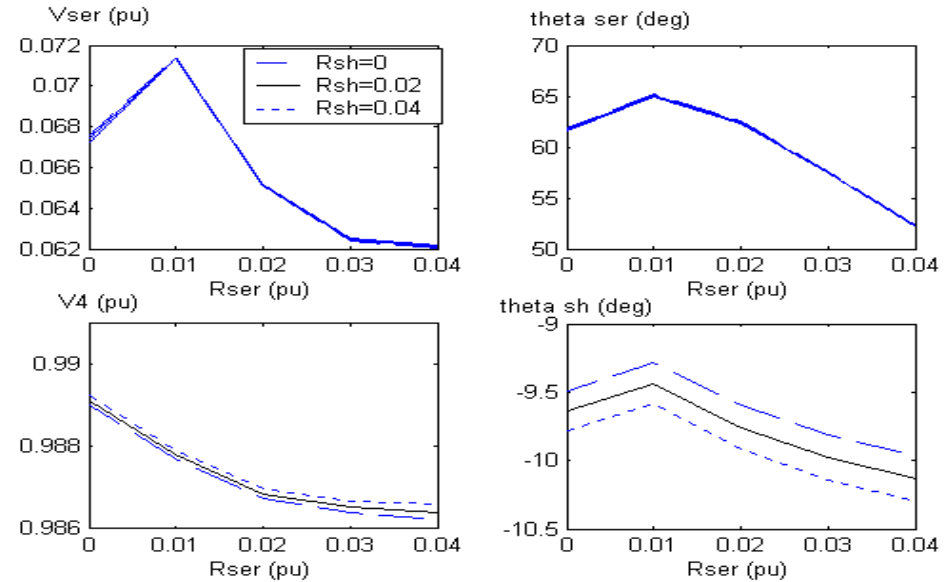

Figure 10: Variation of UPFC control variables versus $\mathrm{R}_{\text {ser }}$.
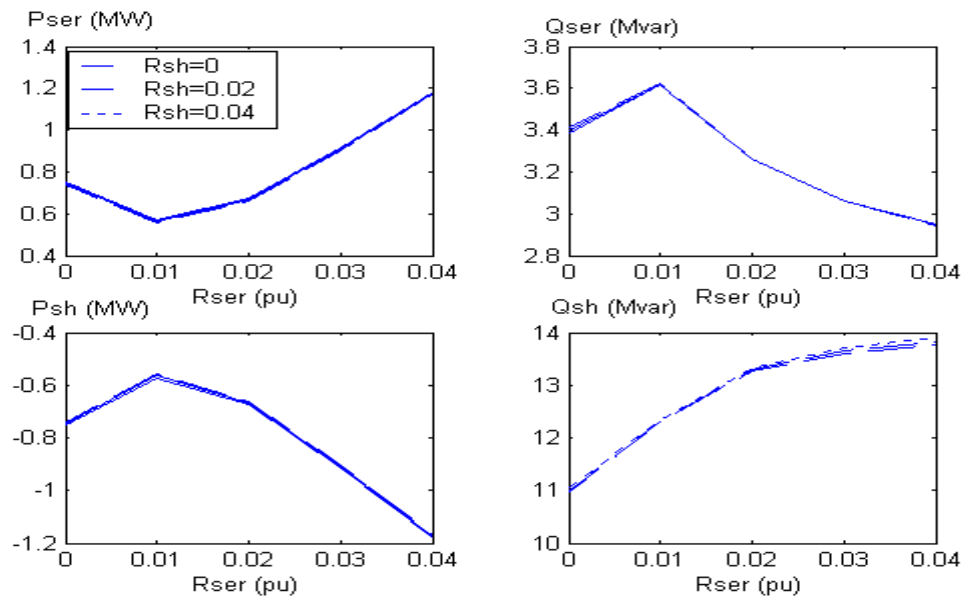

Figure 11: Variation of UPFC converters ratings versus $\mathrm{R}_{\text {ser }}$.

\subsection{Effect of UPFC Initial Conditions on The Number of Iterations}

To show the impact of good UPFC initial conditions upon convergence, different series voltage source initial conditions were used. Table (5) shows three different initial conditions and the number of iteration required for convergence. The second row of the table gives the initial conditions of the series voltage source using Eqns. (20) and (21). Fig. 12 shows the variation of the mismatch at each iteration until convergence. The figure shows that improper selection of initial conditions degrades Newton's quadratic convergence; more seriously, causes the solution to oscillate or even diverge. 
Table 5: Effect of UPFC control variables initial conditions on the number of iterations.

\begin{tabular}{|c|c|c|}
\hline $\mathrm{V}_{\text {ser }}^{\circ}(\mathrm{pu})$ & $\theta_{\text {ser }^{\circ}}($ degree $)$ & No. of iterations \\
\hline 0.0502 & 84 & 5 \\
\hline 0.0502 & 180 & 8 \\
\hline 1.0 & 0 & 11 \\
\hline
\end{tabular}

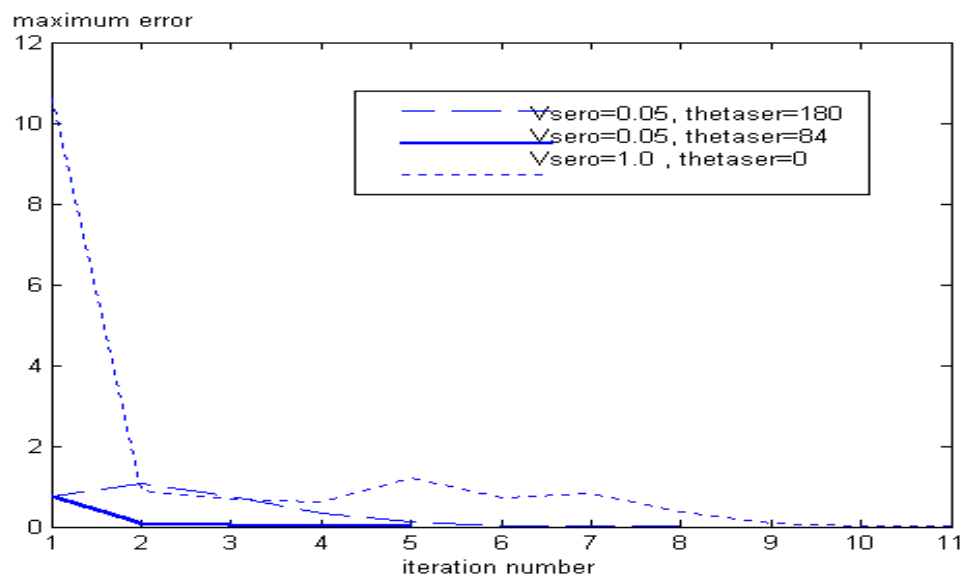

Figure 12: Variation of mismatch at various UPFC control variables initial conditions.

\subsection{Different UPFC Operation Modes}

The UPFC comprehensive NR power flow model enable to show the availability of UPFC to control voltage magnitude and active and reactive power flows simultaneously or individually or in combination. Tables (6) and (7) show the UPFC control variables and converters ratings respectively, for nine modes to obtain the specified values in Table (2). The series and shunt sources reactances are taken to be 1.0 p.u. and the series and shunt sources resistances are neglected. The adopted modes are,

- In mode 1, the voltage magnitude at bus 4 and the active and reactive power flows in line 1-4 are controlled.

- In mode 2, the line active and reactive power are controlled and the voltage magnitude is kept at its value without $\operatorname{UPFC}\left(\mathrm{V}_{4}=\mathrm{V}_{4, \mathrm{org}}=0.9526\right.$ p.u. $)$.

- In mode 3, the line active and reactive power are controlled and the control of voltage magnitude at bus 4 is deactivated. In this mode the shunt voltage source magnitude is chosen to be kept at certain value $\left(\mathrm{V}_{\mathrm{sh}}=1.0 \mathrm{p} . \mathrm{u}\right)$.

- In mode 4, the line active and reactive power are controlled and the shunt converter operate at unity power factor i.e. $\mathrm{Q}_{\mathrm{sh}}=0$ by choosing the shunt voltage source magnitude equal to the voltage magnitude at bus $4\left(\mathrm{~V}_{\mathrm{sh}}=\mathrm{V}_{4}\right)$.

- In modes 5, 6, and 7 the voltage magnitude and active and reactive power flow are respectively, controlled individually. 
- $\quad$ In mode 8 , the voltage magnitude and active power are controlled $\left(\mathrm{Q}_{4-1}=\mathrm{Q}_{4-}\right.$ 1 ,org).

- $\quad$ In mode 9, the voltage magnitude and line reactive power are controlled $\left(\mathrm{P}_{4-1}=\mathrm{P}_{4-1, \text { org }}\right)$.

\subsection{Effects of Incorporating UPFC Control Variables Limits on UPFC Variables Values:}

In order to verify the availability of this UPFC power flow model to identify the limits of the UPFC control variables inside the power flow program, consider that the series voltage source magnitude limits is $0 \leq \mathrm{V}_{\text {ser }} \leq 0.15$ p.u. and the shunt voltage source magnitude is $0.9 \leq \mathrm{V}_{\mathrm{sh}} \leq 1.05 \mathrm{p}$.u. Table (8) shows the UPFC control variables with and without limits consideration, while the required active power through line 1-4 is changed to be $-60 \mathrm{MW}$ and the voltage magnitude and reactive power are still controlled to the values shown in Table (2).

Table 6: UPFC control variables

\begin{tabular}{|c|c|c|c|c|}
\hline Mode & $\begin{array}{l}\mathrm{V}_{\text {ser }} \\
\text { p.u. }\end{array}$ & $\begin{array}{c}\theta_{\text {ser }} \\
\text { Degree }\end{array}$ & $\begin{array}{l}\mathrm{V}_{\mathrm{sh}} \\
\text { p.u. }\end{array}$ & $\begin{array}{c}\theta_{\text {sh }} \\
\text { degree }\end{array}$ \\
\hline \multirow[b]{2}{*}{1} & \multicolumn{4}{|c|}{ Control voltage magnitude, line active and reactive power } \\
\hline & 0.0707 & 53.1 & 1.0129 & -9.6 \\
\hline \multirow[b]{2}{*}{2} & \multicolumn{4}{|c|}{ Control line active and reactive power, $\mathrm{V}_{4}=\mathrm{V}_{4, \mathrm{org}}=0.9526$ p.u. } \\
\hline & 0.0691 & 92.9 & 0.9572 & -9.2 \\
\hline \multirow[b]{2}{*}{3} & \multicolumn{4}{|c|}{ Control line active and reactive power and $\mathrm{V}_{\mathrm{sh}}=1.0$ p.u. } \\
\hline & 0.0676 & 61.9 & 1.0 & -9.5 \\
\hline \multirow[b]{2}{*}{4} & \multicolumn{4}{|c|}{ Control line active and reactive power and $\mathrm{V}_{\text {sh }}=\mathrm{V}_{4}$} \\
\hline & 0.0808 & 11.7 & 0.9255 & -8.97 \\
\hline \multirow[t]{2}{*}{5} & \multicolumn{4}{|c|}{$\begin{array}{l}\text { Control voltage magnitude, } \\
\mathrm{P}_{4-1}=\mathrm{P}_{4-1, \mathrm{org},}, \mathrm{Q}_{4-1}=\mathrm{Q}_{4-1, \mathrm{org}},\end{array}$} \\
\hline & 0.0749 & 28.8 & 1.0083 & -10.3 \\
\hline \multirow[b]{2}{*}{6} & \multicolumn{4}{|c|}{ Control reactive power, $P_{4-1}=P_{4-1, \text { org },}, V_{4}=V_{4, o r g}$} \\
\hline & 0.0533 & 99.2 & 0.9585 & -9.85 \\
\hline \multirow[t]{2}{*}{7} & \multicolumn{4}{|c|}{$\begin{array}{l}\text { Control active power, } \mathrm{Q}_{4-1}=\mathrm{Q}_{4-1, \mathrm{org}}, \\
\qquad \mathrm{V}_{4}=\mathrm{V}_{4, \mathrm{org}}\end{array}$} \\
\hline & 0.0696 & 69.1 & 0.9513 & -9.24 \\
\hline \multirow[b]{2}{*}{8} & \multicolumn{4}{|c|}{ Control voltage magnitude, active power and $\mathrm{Q}_{4-1}=\mathrm{Q}_{4-1, \mathrm{org}}$} \\
\hline & 0.0882 & 36.58 & 1.007 & -9.67 \\
\hline & \multicolumn{4}{|c|}{ Control voltage magnitude, reactive power and $\mathrm{P}_{4-1}=\mathrm{P}_{4-1, \text { org }}$} \\
\hline 9 & 0.0548 & 47 & 1.0142 & -10.25 \\
\hline
\end{tabular}


Table 7: UPFC converters power

\begin{tabular}{|c|c|c|c|c|}
\hline $\begin{array}{c}\text { Mode } \\
\#\end{array}$ & $\begin{array}{l}\mathrm{P}_{\text {ser }} \\
(\mathrm{MW})\end{array}$ & $\begin{array}{c}\mathrm{P}_{\mathrm{sh}} \\
(\mathrm{MW})\end{array}$ & $\begin{array}{c}\mathrm{Q}_{\text {ser }} \\
\text { (MVAR) }\end{array}$ & $\begin{array}{c}\mathrm{Q}_{\text {sh }} \\
\text { (MVAR) }\end{array}$ \\
\hline \multirow[b]{2}{*}{1} & \multicolumn{4}{|c|}{ Control voltage magnitude, line active and reactive power } \\
\hline & 1.3076 & -1.3076 & 3.4094 & 13.104 \\
\hline \multirow[b]{2}{*}{2} & \multicolumn{4}{|c|}{ Control line active and reactive power, $\mathrm{V}_{4}=\mathrm{V}_{4, \mathrm{org}}=0.9526$ p.u. } \\
\hline & 1.1516 & -1.1516 & 3.375 & 4.4075 \\
\hline \multirow[b]{2}{*}{3} & \multicolumn{4}{|c|}{ Control line active and reactive power and $\mathrm{V}_{\text {sh }}=1.0$ p.u. } \\
\hline & 0.7369 & -0.7369 & 3.4124 & 10.977 \\
\hline \multirow[b]{2}{*}{4} & \multicolumn{4}{|c|}{ Control line active and reactive power and $\mathrm{V}_{\mathrm{sh}}=\mathrm{V}_{4}$} \\
\hline & -2.5503 & 2.5503 & 3.3011 & 0 \\
\hline \multirow[t]{2}{*}{5} & \multicolumn{4}{|c|}{$\begin{array}{l}\text { Control voltage magnitude, } \\
\mathrm{P}_{4-1}=\mathrm{P}_{4-1, \mathrm{org},}, \mathrm{Q}_{4-1}=\mathrm{Q}_{4-1, \mathrm{org} .}\end{array}$} \\
\hline & 2.4804 & -2.4804 & 3.0462 & 8.3847 \\
\hline \multirow[b]{2}{*}{6} & \multicolumn{4}{|c|}{ Control reactive power, $\mathrm{P}_{4-1}=\mathrm{P}_{4-1, \text { org },} \mathrm{V}_{4}=\mathrm{V}_{4, \text { org }}$} \\
\hline & -1.1335 & 1.1335 & 2.4327 & 5.6239 \\
\hline \multirow[t]{2}{*}{7} & \multicolumn{4}{|c|}{$\begin{array}{c}\text { Control active power, } \mathrm{Q}_{4-1}=\mathrm{Q}_{4-1, \mathrm{org}}, \\
\mathrm{V}_{4}=\mathrm{V}_{4, \mathrm{org}}\end{array}$} \\
\hline & -0.0729 & 0.0729 & 3.7377 & -1.2331 \\
\hline \multirow[b]{2}{*}{8} & \multicolumn{4}{|c|}{ Control voltage magnitude, active power and $\mathrm{Q}_{4-1}=\mathrm{Q}_{4-1, \mathrm{org}}$, } \\
\hline & 2.4686 & -2.4686 & 4.0461 & 7.0964 \\
\hline \multirow[b]{2}{*}{9} & \multicolumn{4}{|c|}{ Control voltage magnitude, reactive power and $\mathrm{P}_{4-1}=\mathrm{P}_{4-1, \mathrm{org}}$} \\
\hline & 1.2628 & -1.2628 & 2.4557 & 14.367 \\
\hline
\end{tabular}

Table 8: UPFC control variables

\begin{tabular}{||c|c|c|c|c||}
\hline \hline limits & $\mathrm{V}_{\text {ser }}$ (p.u.) & $\theta_{\text {ser }, \text { degree }}$ & $\mathrm{V}_{\text {sh }}$ (p.u). & $\theta_{\text {sh , degree }}$ \\
\hline $\begin{array}{c}\text { Without } \\
\text { limits }\end{array}$ & 0.2147 & 67.0109 & 1.0012 & -4.100 \\
\hline $\begin{array}{c}\text { With } \\
\text { limits }\end{array}$ & 0.15 & 63.959 & 1.0067 & -6.551 \\
\hline \hline
\end{tabular}

\section{CONCLUSIONS}

The following conclusions can be pointed;

1) A UPFC comprehensive NR power flow model has been incorporated in a MATLAB power flow program based on NR algorithm.

2) The effects of UPFC coupling transformers impedances on its control variables and converters ratings which are required to achieve certain operation are detected.

3) When the voltage magnitude and line active and reactive power are controlled simultaneously, the series converter reactive power, voltage source magnitude and angle are affected by its own impedance.

4) The shunt source voltage magnitude and angle are affected by its own impedance and series source resistance.

5) The converters active power are affected by series source resistance only.

6) The shunt converter reactive power is affected by the series source resistance and shunt source reactance.

7) When the control of the voltage magnitude is deactivated, the converters active power become affected by series source resistance and shunt source reactance. 
8) The availability of UPFC to control voltage magnitude, line active and reactive power either simultaneously or individually or in combination of them is affirmed.

9) The results show the influence of the UPFC initial conditions on convergence and iterations number, improper selection of initial conditions degrades Newton's quadratic convergence, or more seriously, causes the solution to oscillate or even diverge.

10) Using this UPFC model, the limits violation of UPFC control variables can be avoided.

\section{REFERENCES}

[1] M.Z El-Sadek “ Power Systems Power Quality”, Book, Mukhtar press, Assiut, 2004.

[2] L. Gyugyi, C.D. Schauder, S.L. Williams, T.R. Rietman, D.R. Torgerson, A. Edris, "The Unified Power Flow Controller: A New Approach to Power Transmission Control", IEEE Trans., Vol. PWRD-10, No. 2, pp. 1085-1097, April 1995.

[3] A. Nabavi-Niaki and M. R. Iravani. "Steady-State and Dynamic Models of Unified Power Flow Controller (UPFC) for Power Systems Studies" presented at 1996 IEBEIPES Winter Meeting96 WM 257-6 PWRS

[4] M. Noroozian, L. Angquist, M. Ghandhari, and G. Anderson, " Use Of UPFC For Optimal Power Flow Control”, IEEE Trans. On Power Delivery, Vol. 12, No. 4, pp. 1629-1634, October 1997.

[5] C. R. Fuerte, E. Acha, and H. Ambriz-Perez, "A comprehensive Newton-Raphson UPFC model for the quadratic power flow solution of practical power networks," IEEE Tran. on Power Systems, No. 1, pp.102-109, 2000.

\section{إدماج نموذج نيوتن -رافسون الشامل لمنظم مسارات القدرة الموحدة في برامج مسارات القدرة}

يعـد مــنظم مســارات القـدرة الموحـدة (UPFC)أحـد أنــواع أنظمـة النقـل للتبـارات المتـرددة المرنـة(FACTS). يهدف هذا البحث إلى إدماج منظم مسـارات القدرة الموحدة في بـرامج مسـارات القدرة باسـتخدام نمـوذج نيوتن -رافسـون الثـامل. و يختلف هذا النمـوذج عـن النمـاذج الأخرى المتاحة في الدراسات السابقة حيث أنه يسمح بالتحكم في القدرة الفعالة و غير الفعالة و قيمـة الجهد كمجموعـة مؤتلفـة أو عدم التحكم في أي منهم. كمـا أن مجموعـة مسن المعـادلات التحليليـة تم إثباتها لكي تعطى شـروط ابتدائيـة جيدة لمنظم مسـارات القدرة الموحدة. و بُظظِِر الحل الحسـابي لهذه المعـادلات خصـائص تقـارب تربيعيـة أو شبه تربيعيـة. و بنـاءا على هذا النموذج ، يمكن حساب متغيرات التحكم و سعة المحولات لمنظم مسارات القدرة الموحدة. كما أنه سبتم إلقاء الضوء على تأثير معاوقات المحولات المرتبطة بمنظم مسارات القدرة الموحدة على متغيرات التحكم و سعة المحولات. 